\title{
Growth Behavior of Pigeonpea [Cajanus cajan (L.) Millsp.] in Pigeonpea based Cropping System in Response to Integrated Nutrient Management Practices in Tarai region of Uttarakhand
}

\author{
Ashutosh Barthwal ${ }^{1}$, V.K. Singh ${ }^{1}$, Shambhoo Prasad ${ }^{3}$, Naveen Singh Rawat $^{2}$ and \\ M.P. Semwal ${ }^{1}$ \\ ${ }^{1}$ Department of Agronomy, ${ }^{2}$ Department of seed Science and Technology, \\ College of Agriculture, Govind Ballabh Pant University of Agriculture \& Technology, \\ Pantnagar, Uttarakhand, India \\ ${ }^{3}$ College of Forestry, Uttarakhand University of Horticulture and Forestry, Ranichauri, Tehri \\ Garhwal, Uttarakhand, India \\ *Corresponding author
}

\section{A B S T R A C T}

\section{Keywords}

Cropping system, Crop growth rate, Relative growth rate, Dry matter accumulation etc.

Article Info

Accepted:

22 January 2019

Available Online:

10 February 2019

\begin{abstract}
A two year field experiment on Growth behavior of Pigeonpea [Cajanus cajan (L.) Millsp.] in Pigeonpea Based Cropping System in response to Integrated Nutrient Management Practices in Tarai region of Uttarakhand was conducted at Norman E. Borlaug Crop Research Centre, GBPUA\&T, Pantnagar, Uttarakhand. Analysis of the two years average data indicated that Pigeonpea + Urd cropping system resulted in Maximum dry matter accumulation (g/plant), Crop growth rate (g/day), Relative growth rate (g/g/day) biological yield and yield of pigeonpea as compared to rest of the cropping system. Application of Recommended Dose of Fertilizer + vermicompost @ $2.5 \mathrm{t} / \mathrm{ha}$ found as effective as Recommended Dose of Fertilizer + Farm Yard Manure @ 5.0 t/ha and improved all the growth and yield parameters of pigeonpea than Recommended Dose of Fertilizer alone. Inoculation of seed with PSB attained significantly higher growth and yield parameters than that obtained without inoculation during both the years.
\end{abstract}

\section{Introduction}

Among pulses pigeonpea a [Cajanus cajan (L.) Millsp.] is the most important rainy season crop in India. The production of pigeonpea has increased over the years. The increase in production is a result of increase in area, however, the overall productivity of pigeonpea has remained stagnant for last several decades (Anonymous, 2016).

Growing of pigeonpea as a sole crop is not economically viable due to its low productivity and longer duration. Intercropping of short duration cereals and pulses provides an opportunity to utilize available resources more efficiently with enhancement of productivity and profitability 
of the system. In India, pigeonpea is generally intercropped with maize, sesamum, soybean, mungbean and groundnut. In general, intercropping has been reported to be more productive than monocropping (Ghosh et al., 2006) this might be through efficient use of light energy and other growth resources. Among the different factors of production, inadequate fertilizer management has remained major constraint forever. Component crops in intercropping systems use the same resources in different forms (Szumigalski and Acker, 2005). The greatest limitation of increasing the productivity of crops in intercropping system is inadequate supply of nutrients since most of the soils are poor in native fertility and continuous application of fertilizers even in balanced form may not sustain soil fertility and productivity.

Thus, balanced fertilization along with sound crop husbandry offers a great scope for increasing productivity. However, when crops are intercropped by increasing the overall density, nutritional deficiency is likely to occur. The optimum dose of nutrients plays an important role in increasing the productivity of these crops. Crop growth rate and Relative growth rate are used extensively in growth analysis of field crops and these physiological parameters are best measure of the total performance of the crop (Nataraja et al., 2006). These growth parameters mainly depend on management practices and climatic condition. The growth attributes and vegetative characters are directly influenced by Resource utilization and availability of nutrients in the soil. With this background, present investigation was planned to investigate the "Growth behavior of Pigeonpea [Cajanus cajan(L.) Millsp.] in Pigeonpea Based Cropping System in response to Integrated Nutrient Management Practices" in Tarai region of Uttarakhand.

\section{Materials and Methods}

A two year (2010 and 2011) field experiment was conducted in $\mathrm{D}_{6}$ block of Norman $\mathrm{E}$. Borlaug Crop Research Centre, G. B. Pant University of Agriculture and Technology, Pantnagar (Uttarakhand). The centre is situated at $29^{0} \mathrm{~N}$ latitude, $79.3^{\circ} \mathrm{E}$ longitude and at the altitude of 243.83 metres above the mean sea level. It is located in the tarai belt of Uttarakhand, $30 \mathrm{Km}$ southwards of foot hills of Shiwalik range of the Himalayas. The maximum temperature during the crop seasons ranged between $13.6-33.3^{\circ} \mathrm{C}$ and $18.4-35.6^{\circ} \mathrm{C}$ while the minimum temperature varied between 5.3-26. ${ }^{\circ} \mathrm{C}$ and $3.7-26.1^{\circ} \mathrm{C}$, respectively. The total rainfall of $1729.2 \mathrm{~mm}$ received during first year which was much lower than that of rainfall of 2032.8 received during second year.

The field was ploughed once, harrowed thrice and leveled properly with the help of tractor drawn implements. Pre-sowing irrigation was not applied as sufficient moisture was available in the soil during both the year. A composite soil sample was taken from the experimental plot before sowing of crops upto a depth $15 \mathrm{~cm}$ and analyzed for different constituents. The soil of the experimental plot was sandy loam in texture. The soil was found high in organic carbon, low in available nitrogen and medium in available phosphorus and potassium content with neutral in soil reaction.

The experiment plot $(4.5 \mathrm{~m} \mathrm{X} 4.0 \mathrm{~m})$ was laid out in split plot design keeping three cropping system as main plot and three fertility status as sub plot with three replications. Among the treatments, Sole Pigeonpea, Pigeonpea + Urdbean (1:2) and Pigeonpea + Maize (1:2)\} was selected as cropping system, whereas, Recommended dose of fertilizer (RDF), Recommended dose of fertilizer (RDF) + Farm Yard Manure (FYM) @ 5.0 t/ha and Recommended dose of fertilizer (RDF) + 
Vermicompost@2.5 t/ha) was selected as fertility status during the course of investigation. The Row spacing for pigeonpea, maize urdbean were $90 \mathrm{~cm}, 45$ $\mathrm{cm}$ and $30 \mathrm{~cm}$ respectively.

Recommended dose of fertilizer (RDF) for both urdbean and pigeonpea i.e. $20 \mathrm{Kg} \mathrm{N}+$ $40 \mathrm{Kg} \mathrm{P}_{2} \mathrm{O}_{5}+30 \mathrm{Kg} \mathrm{K}_{2} \mathrm{O} / \mathrm{ha}$, was applied as basal at the time of sowing. However, in maize $\mathrm{RDF}$ was $120 \mathrm{Kg} \mathrm{N}+60 \mathrm{Kg}_{2} \mathrm{O}_{5}+$ $40 \mathrm{Kg} \mathrm{K}_{2} \mathrm{O} / \mathrm{ha}$. Half of the nitrogen i.e., 60 $\mathrm{Kg} \mathrm{N}$ and full dose of $\mathrm{P}_{2} \mathrm{O}_{5}$ and $\mathrm{K}_{2} \mathrm{O}$ was applied as basal. Remaining half of $\mathrm{N}(60 \mathrm{~kg}$ $\mathrm{N} / \mathrm{ha}$ ) was top dressed in two equal splits, one at knee high stage and another at tasseling stage of the crop. Urea $(46 \% \mathrm{~N})$, Single Super Phosphate $\left(\begin{array}{lll}16 \% & \mathrm{P}_{2} \mathrm{O}_{5}\end{array}\right)$ and Muriate of Potash $\left(60 \% \mathrm{~K}_{2} \mathrm{O}\right)$ were used as source for nitrogen, phosphorus and potassium, respectively. FYM @ 5.0 t/ha and Vermicompost @ $2.5 \mathrm{t} / \mathrm{ha}$ was also applied as per treatment on dry weight basis one week before sowing. Fertilizers in intercropping treatments were given as per row arrangements.

Urdbean (Pant U 31) and maize (Surya) were intercropped with pigeonpea (UPAS 120) as per treatment during both the years of experimentation and the seeds of urdbean/pigeonpea were sown @ $15 \mathrm{~kg} / \mathrm{ha}$ and of maize @ $20 \mathrm{~kg} / \mathrm{ha}$. Pigeonpea and maize were sown on the same day while urdbean was sown 15 and 22 days after pigeonpea and maize sowing in order to avoid the excessive growth. After 15 days of sowing thinning was done in each crop as well as each plot to keep the plant to plant distance at $20 \mathrm{~cm}$ in pigeonpea and maize and $10 \mathrm{~cm}$ in urdbean, during both the years of experimentation. Weeds were controlled manually with the help of Khurpi.

During the investigation morpho-metric traits viz., dry matter accumulation, Mean crop growth rate and Mean relative crop growth rate was calculated for both the year respectively. The following important parameters were calculated according to their formulas.

\section{Dry matter accumulation}

For dry matter accumulation two plants of pigeonpea were selected randomly from different rows from East side in $0.5 \mathrm{~m}$ row length leaving at least one plant as border in each row of each side of each plot and cut at the ground level at 30,60, 90 and 120 DAS and at maturity Pigeonpea. The samples were sun dried first and then kept in oven at $65 \pm 5^{\circ} \mathrm{C}$ till the constant weight was achieved. Later on dry matter accumulation per plant was worked out.

\section{Growth analysis}

Total dry matter (g/plant) was used to calculate different parameter of growth analysis. The sample size was three plants.

a) Mean crop growth rate

$(\mathrm{CGR})=$

$$
(W 2-W 1) /(t 2-t 1)
$$

Where, $\mathrm{W}_{1}$ and $\mathrm{W}_{2}$ are total dry weight per plant at time $t_{1}$ and $t_{2}$, respectively.

b) Mean relative crop growth rate

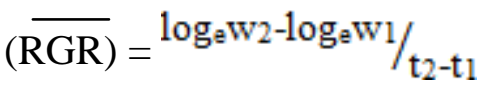

The collected data for various studies in pigeonpea, urdbean and maize crops were subjected to the statistical analysis by using STPR-1, programme developed by department of statistics and mathematics, college of basic science and humanities. Comparison of treatment means was done using critical differences (CD) at 5 per cent level of significance. 


\section{Results and Discussion}

\section{Dry matter accumulation}

Dry matter accumulation in the pigeonpea plant increased with advancement in crop age and reached to maximum at harvest (Table 1). In general, dry matter accumulation recorded during 2011 was higher as compared to that of 2010 at all growth stages. The highest rate of dry matter accumulation was recorded between 90 and 120 DAS and reduced slightly till the harvesting during both the years. All the treatments significantly affected the pigeonpea dry matter accumulation at all the stages of crop growth during both the years. Pigeonpea plants under pigeonpea + urdbean system accumulated significantly more dry matter at all stages during both the years than pigeonpea sole as well as pigeonpea + maize cropping systems. Sole planting of pigeonpea produced significantly more dry matter than pigeonpea + maize cropping system. Maximum dry matter accumulation was found with the application of RDF + vermicompost @ 2.5 t/ha during both the years. Fertility treatments viz. RDF + vermicompost @ 2.5 t/ha and RDF + FYM @ 5.0 t/ha being at par recorded more dry matter over RDF alone. Seed inoculation with PSB accumulated significantly more dry matter per plant of pigeonpea than no inoculation at all the stages during both the years.

\section{Growth analysis}

\section{Mean Crop Growth Rate (CGR)}

In general, mean crop growth rate increased with advancement in crop age upto 120 days and it was recorded maximum between 90120 days. Year 2011 recorded higher CGR than 2010. Cropping system, fertility level and PSB inoculation influenced CGR significantly at all the stages of crop growth during both the years (Table 2). Pigeonpea + urdbean cropping system recorded significantly higher CGR over remaining two systems at all the growth stages during both the years except 0-30 day in 2011 and 90-120 day in 2010. Pigeonpea sole ranked second which attained significantly higher CGR than pigeonpea + maize at all the growth stages during both the years. Treatments RDF + vermicompost @ 2.5 t/ha and RDF + FYM @ $5.0 \mathrm{t} / \mathrm{ha}$ were statistically comparable and produced higher CGR over RDF alone at all the stage during both the years. Seed inoculation with PSB increased CGR significantly over no inoculation at all the growth stages of crop growth during both the years.

\section{Mean Relative Growth Rate (RGR)}

Under present investigation increasing trend in RGR was noticed with increase in crop age upto 60-90 days stage. Thereafter, it decreased at 90-120 days stage during both the years. The maximum RGR was calculated during 60-90 days stage during both the years. All the treatments (Cropping system, fertility level and PSB inoculation) brought significant differences in RGR at different crop stages during both the years (Table 3). On an averaged RGR was more during 2011 as compared to 2010. Pigeonpea + urdbean cropping system improved RGR of the pigeonpea plants significantly over remaining systems at different stages during both the years.

Pigeonpea + maize intercropping system recorded minimum RGR at all the stages during both the years. Application of RDF + vermicompost@2.5 t/ha being at par with $\mathrm{RDF}+\mathrm{FYM} @ 5.0$ t/ha produced significantly higher RGR of pigeonpea plant over RDF alone. Inoculation of seed with PSB attained significantly higher RGR than that obtained without inoculation during both the years. 


\section{Yield and its components}

In present study, yield and yield component its components of pigeonpea significantly influenced by intercropping system (Table 4). Maximum pigeonpea grain yield (1216 and $1892 \mathrm{~kg} / \mathrm{ha}$ ) was recorded when intercropped with urd than sole pigeonpea (1025 and 1415 $\mathrm{kg} / \mathrm{ha}$ ) while statistically minimum pigeonpea grain yield (656 and $675 \mathrm{~kg} / \mathrm{ha}$ ) was recorded when intercropped with maize. Similar trend was observed for biological yield, no. of pods per plant, grain weight, straw yield during both the years. Application of RDF + vermicompost @ 2.5 t/ha significantly higher number of pods/plant (138.52 and 149.19), Grain weight (38.05 and 52.05 g/plant), straw yield (4567 and $6058 \mathrm{~kg} / \mathrm{ha}$ ), biological yield (5592 and $7447 \mathrm{~kg} / \mathrm{ha}$ ) and yield (1029 and $1376 \mathrm{~kg} / \mathrm{ha}$ ) significantly over RDF alone, during both the years respectively. However the difference between application of either FYM @ 5.0 t/ha or vermicompost @ 2.5 t/ha were remain non significant.

Crop growth analysis, one of the basic approaches to the analysis of yield influencing factors and plant development as net photosynthate accumulation is naturally integrated over time. Growth analysis is frequently used by plant physiologist and agronomists. Achieving higher growth attributes such as crop growth rate (CGR) is well governed by utilization of available resources, fertility levels, available nutrients and favorable climatic condition. Resource utilization had remarkable effect on most growth analysis of pigeonpea. Crop growth rate (CGR), the gain in weight of a community of plants on a unit of land in a unit time, is used extensively in growth analysis of crops. It is regarded as the most common representative of growth function because it represents the net results of photosynthesis, respiration and canopy area interaction.
In general, year 2011 recorded higher CGR, RGR, dry matter accumulation, yield attributes and yield than 2010. Here it may be pointed out that total rainfall of $1729.2 \mathrm{~mm}$ received during first year which was much lower than that of rainfall of 2032.8 received during second year. Sufficient moisture availability and favorable climatic condition during second year paved the way for better plant growth and yield of pigeonpea.

Dry matter accumulation plays significant role in plant proliferation. Dry matter accumulation in the pigeonpea plant increased with advancement in crop age and reached to maximum at harvest. While mean crop growth rate increased upto 120 days and it was recorded maximum between 90-120 days. Under present investigation increasing trend in RGR was noticed with increase in crop age upto 60-90 days stage. Thereafter, it decreased at 90-120 days stage during both the years. The maximum RGR was calculated during 60-90 days stage during both the years. Growth parameters value increased at the lowest rate at initial stage because of slow growth and development of pigeonpea at early stages and competition by intercrops. The increase in value was tremendous between 90 DAS to maturity in all the intercropping systems which was due to grand growth of pigeonpea during this period. The crop growth rate simply indicates the change in dry weight over a period of time. A possible justification could be increase in CGR values which directly related with an increase in dry matter accumulation values. However, relative growth rate (RGR) denotes the rate of growth per unit dry matter. It is similar to compound interest, wherein interest is also added to the principal to calculate interest.

The growth, yield attributes and yield of pigeonpea measured in terms of dry matter accumulation (g/plant) (Table 1), Crop growth rate (Table 2), Relative growth rate 
(Table 3), yield attributes and yield (Table 4) was in superior order under pigeonpea + urdbean intercropping system as compared to pigeonpea sole and pigeonpea + maize. This might be due to the optimum utilization of growth resources which turn in maximum growth and development leads to higher crop growth rate. The beneficial effect of urdbean reflected on pigeonpea was probably due to addition of $\mathrm{N}$ in soil by decay of urdbean nodules and also due to insignificant crop competition persuaded by urdbean. Here it may be pointed out that, the competition between pigeonpea and maize for space, sunlight, nutrients, water etc. was more as compared to urdbean which resulted in poor growth and development of pigeonpea under pigeonpea + maize intercropping system. Lowest dry matter accumulation (g/plant), Crop growth rate, Relative growth rate, yield attributes and yield of pigeonpea with maize as intercrop might be due to more competition of component crops for growth resources early stages of plant growth. Reduction in these parameters of pigeonpea with such intercrops has also been reported by Saxena (1972), Saxena and Yadav (1975), Dubey et al., (1991) and Rafey (1992). Similar findings have also been reported by Sharma et al., (2010), Yadav et al., (1997), Bajpai and Singh (1992), and Tewari et al.,(1989) In an intercropping system, Rao and Willey (1983) noticed that the sorghum reduced the total branch number in pigeonpea but had little effect on the number of pod bearing branches. Chaudhary and Thakur (2005) from Bihar reported significantly higher plant height and branches/plant in pigeonpea when grown as sole crop as compared to intercropping with maize.

Application of RDF + vermicompost @ 2.5 t/ha significantly higher growth parameter, yield attributes and yield over RDF alone. While reviewing the manurial work already done, it was postulated that, the crop of pigeonpea responded well to the application of FYM or vermicompost along with RDF as FYM or vermicompost, itself is a source of different primary, secondary and micronutrients. When these organic manures are applied with inorganic and biofertilizers, act as a slow release source of nutrient. It forms different complexes with the metal cations present in the soil and restricts their losses from the system. In view of these considerations, in the present study application of FYM @ 5.0 t/ha or vermicompost @ 2.5 t/ha along with recommended dose of fertilizer improved the dry matter accumulation (Table), The positive response of pigeonpea to FYM or vermicompost application have also been reported by Dubey and Gupta (1996), Singh et al., (2008) and Nalatwadmath et al., (2003), respectively. Sarkar et al., (1997) also reported favorable response of pigeonpea to FYM and vermicompost application.

Inoculation of seed with PSB attained significantly higher Dry matter accumulation, CGR, RGR, yield attributes and yield than that obtained without inoculation during both the years. Here, it may be elucidated that, the establishment and growth of crop plants depend much on a sound root system and it is also true to postulate that plants with better developed root system are able to absorb nutrients from deeper layer of the soil profile and hence, they gain in weight and vigour. It may be pointed out that precipitated form of phosphorus i.e. Orthophosphate $\left(\mathrm{H}_{2} \mathrm{PO}_{4}{ }^{-1}\right.$ or $\mathrm{HPO}_{4}{ }^{2-}$ ), is adsorbed by $\mathrm{Fe}^{3+}, \mathrm{Ca}^{2+}$ or $\mathrm{Al}^{3+}$ oxides in soil through legend exchange and become unavailable to plants. PSB solubilze the fixed phosphorus by production of low molecular weight organic acids siderophores (Vassilev et al., 2006) and secretion of phenolic compounds and humic substances. Goldstein (1995) also reported that out of organic acids which solubulize fixed phosphorus, gluconic acid and ketogluconic acid are mainly produced by soil microorganisms. 
Table.1 Effect of different treatments on plant dry matter accumulation (g/plant) of pigeonpea at different stages of crop growth states

\begin{tabular}{|c|c|c|c|c|c|c|c|c|c|c|}
\hline \multirow[t]{3}{*}{ Treatment } & \multicolumn{10}{|c|}{ Dry matter accumulation (g/plant) } \\
\hline & \multicolumn{2}{|c|}{30 DAS } & \multicolumn{2}{|c|}{60 DAS } & \multicolumn{2}{|c|}{90 DAS } & \multicolumn{2}{|c|}{120 DAS } & \multicolumn{2}{|c|}{ At harvest } \\
\hline & 2010 & 2011 & 2010 & 2011 & 2010 & 2011 & 2010 & 2011 & 2010 & 2011 \\
\hline \multicolumn{11}{|l|}{ Intercropping system } \\
\hline Sole pigeonpea & 2.31 & 2.92 & 8.21 & 9.67 & 28.88 & 29.63 & 56.75 & 57.89 & 75.71 & 80.09 \\
\hline Pigeonpea + Urdbean & 2.88 & 3.62 & 11.52 & 14.06 & 41.13 & 41.26 & 66.05 & 94.06 & 112.37 & 117.27 \\
\hline Pigeonpea + Maize & 1.77 & 2.24 & 6.07 & 7.62 & 22.62 & 24.79 & 48.16 & 49.69 & 67.64 & 63.14 \\
\hline SEm \pm & 0.12 & 0.15 & 0.51 & 0.44 & 0.81 & 0.71 & 0.67 & 0.46 & 0.67 & 0.47 \\
\hline CD at $5 \%$ & 0.47 & 0.62 & 2.03 & 1.75 & 3.17 & 2.79 & 2.65 & 1.80 & 2.65 & 1.83 \\
\hline \multicolumn{11}{|l|}{ Fertility level } \\
\hline RDF & 1.90 & 2.09 & 6.87 & 8.87 & 27.08 & 27.22 & 49.78 & 56.66 & 75.70 & 72.26 \\
\hline RDF + FYM @ 5 t/ha & 2.44 & 2.60 & 9.16 & 10.93 & 32.26 & 33.40 & 59.91 & 71.29 & 89.34 & 92.89 \\
\hline $\begin{array}{l}\text { RDF +Vermi. @ } 2.5 \\
\text { t/ha }\end{array}$ & 2.46 & 2.62 & 9.78 & 11.55 & 33.28 & 35.06 & 61.26 & 73.69 & 90.68 & 95.29 \\
\hline SEm \pm & 0.09 & 0.08 & 0.46 & 0.51 & 0.71 & 1.03 & 1.09 & 1.20 & 1.10 & 1.22 \\
\hline CD at $5 \%$ & 0.28 & 0.25 & 1.34 & 1.49 & 2.04 & 2.98 & 3.17 & 3.48 & 3.18 & 3.51 \\
\hline \multicolumn{11}{|l|}{ PSB Inoculation } \\
\hline PSB & 1.95 & 2.20 & 7.94 & 9.11 & 29.35 & 27.94 & 51.13 & 65.21 & 82.24 & 83.51 \\
\hline No PSB & 2.58 & 2.67 & 9.27 & 10.99 & 31.39 & 32.84 & 58.84 & 69.85 & 88.24 & 89.12 \\
\hline SEm \pm & 0.08 & 0.07 & 0.38 & 0.42 & 0.57 & 0.84 & 0.89 & 0.98 & 0.90 & 0.99 \\
\hline CD at $5 \%$ & 0.23 & 0.21 & 1.09 & 1.21 & 1.67 & 2.43 & 2.59 & 2.84 & 2.61 & 2.62 \\
\hline
\end{tabular}


Table.2 Effect of different treatments on mean crop growth rate (CGR) of pigeonpea at different stages of crop growth

\begin{tabular}{|c|c|c|c|c|c|c|c|c|}
\hline \multirow[t]{3}{*}{ Treatment } & \multicolumn{8}{|c|}{ Crop Growth Rate (g/day) } \\
\hline & \multicolumn{2}{|c|}{ 0-30 days } & \multicolumn{2}{|c|}{ 30-60 days } & \multicolumn{2}{|c|}{ 60-90 days } & \multicolumn{2}{|c|}{ 90-120 days } \\
\hline & 2010 & 2011 & 2010 & 2011 & 2010 & 2011 & 2010 & 2011 \\
\hline Sole pigeonpea & 0.077 & 0.076 & 0.197 & 0.246 & 0.689 & 0.664 & 0.928 & 0.943 \\
\hline Pigeonpea + Urdbean & 0.091 & 0.092 & 0.292 & 0.376 & 0.987 & 0.908 & 0.829 & 1.260 \\
\hline SEm \pm & 0.003 & 0.006 & 0.020 & 0.016 & 0.030 & 0.022 & 0.030 & 0.027 \\
\hline CD at $5 \%$ & 0.010 & NS & 0.070 & 0.065 & 0.100 & 0.088 & NS & 0.106 \\
\hline \multicolumn{9}{|l|}{ Fertility level } \\
\hline RDF & 0.063 & 0.069 & 0.165 & 0.226 & 0.673 & 0.612 & 0.759 & 0.981 \\
\hline RDF+FYM@ 5 t/ha & 0.082 & 0.087 & 0.223 & 0.277 & 0.770 & 0.749 & 0.921 & 1.260 \\
\hline CD at $5 \%$ & 0.009 & 0.008 & 0.045 & 0.050 & 0.088 & 0.103 & 0.132 & 0.161 \\
\hline \multicolumn{9}{|l|}{ PSB Inoculation } \\
\hline PSB & 0.065 & 0.073 & 0.165 & 0.223 & 0.514 & 0.535 & 0.458 & 0.887 \\
\hline No PSB & 0.087 & 0.090 & 0.256 & 0.311 & 0.970 & 0.895 & 1.281 & 1.460 \\
\hline SEm \pm & 0.002 & 0.002 & 0.012 & 0.014 & 0.025 & 0.029 & 0.037 & 0.045 \\
\hline CD at $5 \%$ & 0.007 & 0.007 & 0.037 & 0.041 & 0.072 & 0.084 & 0.108 & 0.131 \\
\hline
\end{tabular}


Table.3 Effect of different treatments on mean Relative Growth Rate (RGR) of pigeonpea at different stages of crop growth

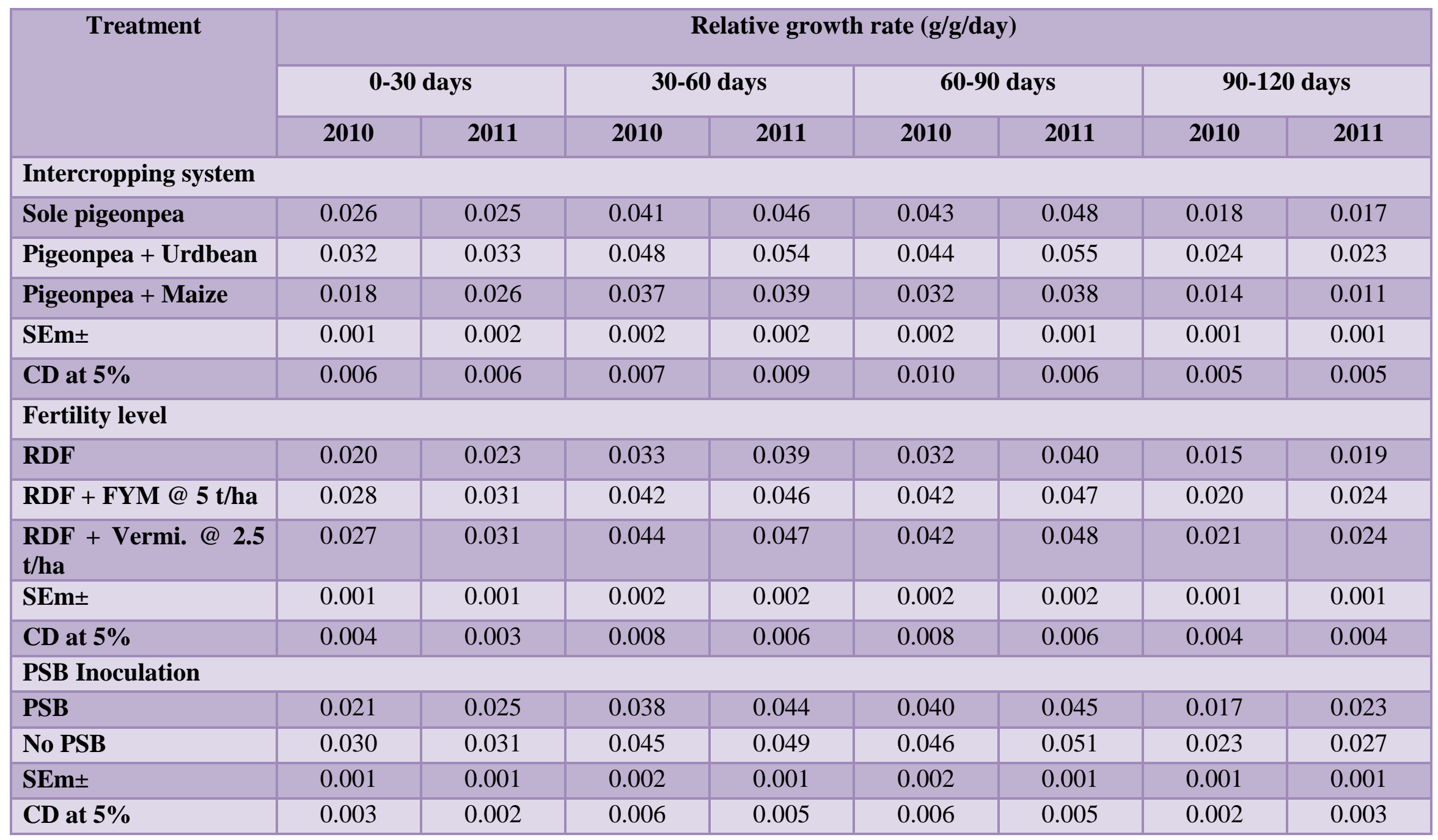


Table.4 Yield attributes and yield of pigeonpea as influenced by cropping system and fertility levels

\begin{tabular}{|c|c|c|c|c|c|c|c|c|c|c|}
\hline \multirow{2}{*}{$\begin{array}{l}\text { Treatment } \\
\text { Intercropping system }\end{array}$} & \multicolumn{2}{|c|}{$\begin{array}{c}\text { No. of } \\
\text { pods/plant }\end{array}$} & \multicolumn{2}{|c|}{$\begin{array}{l}\text { Grain Weight } \\
\text { (g/plant) }\end{array}$} & \multicolumn{2}{|c|}{$\begin{array}{l}\text { Straw Yield } \\
(\mathrm{kg} / \mathrm{ha})\end{array}$} & \multicolumn{2}{|c|}{$\begin{array}{c}\text { Biological Yield } \\
(\mathrm{kg} / \mathrm{ha})\end{array}$} & \multicolumn{2}{|c|}{ Yield (kg/ha) } \\
\hline & 2010 & 2011 & 2010 & 2011 & 2010 & 2011 & 2010 & 2011 & 2010 & 2011 \\
\hline Sole pigeonpea & 130.2 & 139.03 & 38.14 & 51.14 & 4777 & 6481 & 5802 & 7910 & 1025 & 1415 \\
\hline Pigeonpea + Urdbean & 177.16 & 185.45 & 48.44 & 63.44 & 5419 & 8240 & 6641 & 10132 & 1216 & 1892 \\
\hline Pigeonpea + Maize & 103.29 & 118.13 & 25.08 & 39.08 & 3444 & 3280 & 4098 & 3955 & 656 & 675 \\
\hline SEm \pm & 1.08 & 2.06 & 0.94 & 0.93 & 86 & 26 & 135 & 66 & 35 & 26 \\
\hline CD at $5 \%$ & 3.13 & 5.95 & 2.7 & 2.69 & 271 & 105 & 407 & 211 & 135 & 106 \\
\hline \multicolumn{11}{|l|}{ Fertility level } \\
\hline RDF & 134.6 & 144.85 & 35.57 & 49.57 & 4271 & 5873 & 5150 & 7076 & 826 & 1190 \\
\hline RDF + FYM @ 5 t/ha & 137.93 & 148.58 & 38.04 & 52.04 & 4617 & 6071 & 5666 & 7473 & 1050 & 1389 \\
\hline $\begin{array}{l}\text { RDF +Vermi. @ } 2.5 \\
\text { t/ha }\end{array}$ & 138.52 & 149.19 & 38.05 & 52.05 & 4567 & 6058 & 5592 & 7447 & 1029 & 1376 \\
\hline SEm \pm & 1.13 & 1.28 & 0.95 & 0.94 & 98 & 26 & 148 & 66 & 70 & 40 \\
\hline CD at $5 \%$ & 3.26 & 3.72 & 2.73 & 2.72 & 296 & 105 & 432 & 211 & 202 & 106 \\
\hline \multicolumn{11}{|l|}{ PSB Inoculation } \\
\hline PSB & 135.49 & 145.87 & 36.08 & 50.08 & 4555 & 5952 & 5395 & 7422 & 888 & 1283 \\
\hline No PSB & 138.54 & 149.21 & 38.36 & 52.36 & 4641 & 6058 & 5654 & 7433 & 1044 & 1376 \\
\hline SEm \pm & 0.92 & 1.05 & 0.73 & 0.77 & 74 & 26 & 111 & 52 & 61 & 13 \\
\hline CD at $5 \%$ & 2.66 & 3.03 & NS & NS & NS & 79 & NS & NS & NS & 66 \\
\hline
\end{tabular}


These organic acids are the source of biotical generated $\mathrm{H}^{+}$ions, which are able to dissolve the mineral phosphate and to make it available for the plants. Thus, PSB inoculation solubilizes native phosphorus, bringing more phosphorus to soil solution which ultimately increased $\mathrm{P}$ uptake and enhanced root and shoot growth and finally more dry matter accumulation. These results are in close conformity with those obtained by Singh and Yadav (2008) on pigeonpea.

To summarize the overall results of this study it is concluded that intercropping of pigeonpea with urdbean in combination with RDF+Vermicompost@ 2.5 t/ha along with seed inoculation with PSB accelerated the dry matter accumulation, Crop growth rate, relative growth rate yield attributes as well as yield of pigeonpea in Tarai region of Uttarakhand.

\section{Acknowledgement}

The financial assistance provided during the course of investigation by G.B. Pant University of Agriculture \& Technology, Pantnagar is duly acknowledged.

\section{References}

Anonymous, 2016. Area and Production of pigeonpea in India. http//www.indiastat. com

Bajpai, R.P., Singh, V.K., 1992. Fertilizer of pigeonpea (Cajanus cajan)-based intercropping in rainfed condition. Indian J. Agron. 37(4): 655-658

Chaudhary, S.K. and Thakur, S.K. 2005. Productivity of pigeonpea (Cajanus cajan) based intercrops. Indian $J$. Agric. Sci., 75 (8): 496-497.

Dubey, O.P., Garg, D.C., Dixit, J.P. and Tiwari, K.P. 1991. Intercropping in short duration pigeonpea. Indian $J$. Agron. 36(2): 253-254.
Dubey, S.K. and Gupta, B. 1996. Response of soybean to rock phosphate applied with Pseudomonas striata in a Typic chromustert. J. Indain Soc. Soil Sci. 44: 252-255.

Ghosh, P.K., Manna, M.C., Bandyopadhyay, K.K., Tripathi, A., Wanjari, A.K., Hati, K.M., Misra, A.K., 2006. Inter specific interaction and nutrient use in soybean/sorghum intercropping system. Agron. J. 98: 1097-1108.

Goldstein, A. H. 1995. Recent progress in understanding the molecular genetics and biochemistry of calcium phosphate solubilization by Gramnegative bacteria. Biol. Agri. Hort. 12:185-193.

Nalatwadmath, S.K., Rao, M.S., Rama, Mohan, Patil, S.L., Jayaram, N.S., Bhola, S.N. and Prasad, A. 2003. Long term effects of integrated nutrient management on crop yields and soil fertility status in vertisols of Bellary Indian J. Agric. Res. 37(1): 64-67.

Rafey, A. and Prasad, N.K. 1992. Biological potential and economics feasibility of maize (Zea mays) + pigeonpea (Cajanus cajan) intercropping system in dry lands. Indian J. Agric. Sci. 62 (2): 110-113.

Rao, M.R. and Willey, R.W. 1983. Effects of pigeonpea plant population and row arrangement in sorghum/pigeonpea intercropping. Field Crops Res., 7(3):203-212.

Sarkar, R.K., Shith, D., Chakraborty. 1997. Effect of levels and sources of phosphorus with and without farmyard manure on pigeonpea (Cajanus cajan) under rainfed condition. Indian $J$. Agron. 42 (1): 120-123.

Saxena, M.C. 1972. Concept of parallel multiple cropping. Bull. Indian Soc. Agron., New Delhi. pp. 32-50. 
Saxena, M.C. and Yadav, D.S. 1972. Field studies on parallel cropping with short duration arhar. Paper presented in the symposium on multiple cropping, organized by the Indian Society of Agronomy on 7th and 8th October at HAU, Hissar. pp. 232-238.

Sharma, A., Pandit S., Rathod, Mohan C. 2010. Integrated nutrient management in pigeonpea (cajanus cajan) based intercropping systems under rainfed conditions Karnataka J. Agric. Sci. 23(4): 584-589.

Singh, R.S. and Yadav, M.K. 2008. Effect of phosphorus and biofertilizers on growth, yield and nutrient uptake of long duration pigeonpea under rainfed condition. J. Food Leg., 21(1): 46-48.

Singh. A., Singh, V.K., Rana, N.S., Kumar, S., Panwar, G.S. and Kumar, Y. 2008. Response of urdbean to farmyard manure and phosphorus application under urdbean-wheat cropping sequence. J. Food Legumes 21(2): 119121.

Szumigalski, A. and Acker, R. V. 2005. Weed suppression and crop production in annual intercrops. Weed Science 53: 813-25.

Tewari, A.N., Singh, K.K. and Rathi, K.S.1989. Note on compatibility of component crops involving pigeonpea based cropping system. Indian $J$. Agron. 34(4): 469-478.

Vassilev, N., Vassileva, M. and Nikolaeva, I. 2006. Simultaneous P-solubilizing and biocontrol activity of microorganisms: potentials and future trends. Appl Microbiol Biotechnol., 71: 137-144.

Yadav, R.P., Sharma, R.K. and Shrivastava, U.K. 1997. Fertility management in pigeonpea (Cajanus cajan)-based intercropping system under rainfed conditions. Indian J. Agron. 42(1): 4649.

\section{How to cite this article:}

Ashutosh Barthwal, V.K. Singh, Shambhoo Prasad, Naveen Singh Rawat and Semwal, M.P. 2019. Growth Behavior of Pigeonpea [Cajanus cajan (L.) Millsp.] in Pigeonpea based Cropping System in Response to Integrated Nutrient Management Practices in Tarai region of Uttarakhand. Int.J.Curr.Microbiol.App.Sci. 8(02): 3101-3112.

doi: https://doi.org/10.20546/ijcmas.2019.802.363 